SAINTIFIK, Vol.5, No.1, Januari 2019, pp. 63 69

ISSN 2407-4098 (print)

ISSN 2622-8904 (online)

\title{
Hubungan Nilai Matematika Rekayasa Terhadap Nilai Analisa Struktur Mahasiswa Teknik Sipil Universitas Sulawesi Barat
}

\author{
Milawaty Waris $*^{1}$, Nurmiati Zamad ${ }^{2}$ \\ ${ }^{1,2}$ Universitas Sulawesi Barat \\ e-mail: *11mayla_132@yahoo.com, ${ }^{2}$ nurmiatizamad@ rocketmail.com
}

\begin{abstract}
Abstrak
Penelitian ini bertujuan untuk mengetahui hubungan antara nilai mata kuliah Matematika rekayasa terhadap nilai mata kuliah Analisa struktur yang diperoleh mahasiswa teknik sipil Universitas Sulawesi Barat. Penelitian ini tergolong dalam penelitian kuantitatif dengan pendekatan data berbentuk angka. Jenis penelitian yang digunakan bersifat penelitian analitik korelatif menggunakan program aplikasi software SPSS versi 21, Populasi pada penelitian ini adalah mahasiswa teknik sipil universitas sulawesi barat, yang telah menempuh mata kuliah Matematika rekayasa dan Analisa Struktur. Adapun Teknik pengambilan sampel yang digunakan dalam penelitian ini adalah teknik Simple Random Sampling. Analisis statistik yang digunakan dalam penelitian ini adalah analisis korelasi pearson (product moment). Hasil analisis diperoleh Berdasarkan hasil penelitian mengenai hubungan antara nilai Matematika rekayasa dan Analisa struktur digolongkan sedang. Artinya pengaruhnya sedikit. Meskipun berkorelasi positif namun hasilnya signifikan atau tidak bisa digeneralisasikan ke dalam populasi. Hal ini menunjukkan bahwa nilai mata kuliah matematika rekayasa yang diperoleh tidak berhubungan dengan nilai mata kuliah analisa struktur yang diperoleh. Korelasi antara nilai Matematika rekayasa terhadap nilai analisa struktur adalah sebesar 0.435 dengan signifikansi pada taraf kesalahan 5\% dan didapat $r_{\text {-tabel }} 0,361$ maka $\left(r_{\text {-hitung }}=0,435>r_{\text {-tabel }}=\right.$ 0,361 ) berarti Ho diterima, namun hubungan antara nilai Matematika rekayasa terhadap nilai mata kuliah analisa struktur tidak ada hubungannya karena meskipun nilai mata kuliah Matematika rekayasa tinggi belum tentu nilai mata kuliah analisa struktur juga tinggi.
\end{abstract}

Kata kunci: Matematika rekayasa, Analisa Struktur, analisis korelasi pearson, uji signifikansi

\section{PENDAHULUAN}

Mata kuliah matematika rekayasa dalam ilmu teknik sipil adalah kelanjutan dari mata kuliah kalkulus I dan kalkulus II. Mata kuliah matematika rekayasa merupakan mata kuliah pengetahuan dasar yang sangat diperlukan dalam menempuh jenjang pendidikan yang lebih tinggi. Mata kuliah matematika rekayasa dalam teknik sipil terbagi dua yaitu matematika rekayasa I dan matematika rekayasa II, mata kuliah ini merupakan mata kuliah ilmu berhitung yang menjadi sarana berfikir ilmiah yang sangat diperlukan untuk menambah kemampuan berfikir logis, sistematis dan kritis dalam diri peserta didik. Mata kuliah matematika rekayasa merupakan sarana penunjang dalam mempelajari mata pelajaran lain terutama yang di dalamnya berkenaan dengan unsur-unsur perhitungan yang bersifat aplikatif.

Mata kuliah matematika rekayasa erat hubungannya dengan mata kuliah lainnya di program studi teknik sipil dan ada hubungannya dengan mata kuliah analisa struktur, karena

Received December 26 $6^{\text {st }}$ 2018; Revised December 30 ${ }^{\text {th }}$, 2018; Accepted January $5^{\text {th }}$, 2019 
materi yang pada mata kuliah matematika rekayasa sebagai dasar untuk mata kuliah analisa struktur. Hal ini tentu memunculkan anggapan jika mahasiswa sudah mampu menguasai matematika rekayasa, maka mahasiswa akan mampu menguasai ilmu analisa struktur.

Menurut Iswadi (2006) Dijelaskan bahwa matematika berkaitan erat dengan bilangan. Bahkan kamus besar bahasa Indonesia mendefinisikan matematika antara lain sebagai ilmu tentang bilangan-bilangan.

Analisa struktur atau dikenal juga sebagai mekanika rekayasa merupakan bidang ilmu utama yang dipelajari di ilmu teknik sipil. Pokok utama dari ilmu tersebut adalah mempelajari perilaku struktur terhadap beban yang bekerja padanya. Perilaku struktur tersebut umumnya adalah lendutan dan gaya-gaya (gaya reaksi dan gaya internal).

Dalam mempelajari tentang perilaku analisa struktur suatu perencanaan, maka hal-hal yang perlu diperhatikan adalah stabilitas, keseimbangan gaya, kompatibilitas antara deformasi dan jenis tumpuan elastisitas. Dari perhitungan gaya-gaya dan lendutan yang diperoleh, maka selanjutnya perencanaan analisa struktur dapat direncanakan dimensinya berdasarkan material yang digunakan secara aman dan nyaman dalam hal ini lendutan yang terjadi tidak berlebihan dalam menerima pembebanan.

Dari penelitian awal yang diambil pada beberapa mahasiswa program studi teknik sipil di Universitas Sulawesi Barat, Mahasiswa berpandangan bahwa mata kuliah analisa struktur adalah mata kuliah yang baru dan perlu tenaga tambahan untuk dapat memahami lebih dalam terkait mata kuliah analisa struktur karena termasuk pelajaran berhitung dan aplikatif. Sementara dari wawancara langsung dengan beberapa dosen bidang studi matematika rekayasa dan analisa struktur, bahwa ada dosen yang masih menyertai materi mata kuliah matematika rekayasa sebagai pendukung yang berhubungan dengan materi analisa struktur dalam proses pembelajarannya. Sedangkan ada juga dosen yang cukup mengajarkan materi yang sudah ada dalam buku ajar analisa struktur. Dari kedua pernyataan tersebut didapat kesimpulan bahwa ternyata mahasiswa yang menerima materi kuliah disertai dengan materi matematika rekayasa memiliki prestasi belajar yang lebih baik dari pada mahasiswa yang materi kuliahnya hanya mengikuti materi pembelajaran melalui buku ajar.

Kesinambungan interaksi antara dua variabel atau lebih yang dapat memudahkan proses pengenalan satu hal dengan hal lain. Hubungan dalam suatu mata pelajaran dapat memberikan pengaruh terhadap mata pelajaran yang lain. Suatu perolehan nilai adalah suatu taksiran, sifatsifat (hal-hal) penting yang dianggap penting atau yang berguna bagi kemanusiaan yang dapat mendorong manusia mencapai tujuannya

Program studi teknik sipil fakultas teknik Universitas Sulawesi Barat adalah salah satu program studi yang terdapat di Universitas Sulawesi Barat yang mempunyai visi dan misi menghasilkan mahasiswa yang unggul dalam disiplin bidang ilmu teknik sipil dan dapat meraih pekerjaan setelah menyelesaikan studinya. Tenaga pendidik dalam hal ini dosen yang mengajar pada program studi teknik sipil harus memiliki pengalaman lebih dan berkompeten dalam bidang ilmu ketekniksipilan, Tenaga pendidik dalam hal ini dosen diharapkan mampu mengajar dan membimbing mahasiswa dalam hal ketekniksipilan untuk mencetak lulusan yang siap kerja dalam menghadapi tantangan globalisasi era milenial 4.0. Berdasarkan kajian tersebut, maka peneliti tertarik untuk membahasnya dalam bentuk penelitian yang berjudul "Hubungan Nilai Matematika Rekayasa Terhadap Nilai Analisa Struktur Mahasiswa Teknik Sipil Universitas Sulawesi Barat".

\section{METODE PENELITIAN}

\subsection{Pendekatan penelitian}

Penelitian ini dilaksanakan pada program studi Teknik Sipil Fakultas Teknik Universitas Sulawesi Barat, pada semester genap tahun ajaran 2015/2016. Penelitian ini tergolong penelitian kuantitatif dengan pendekatan data berbentuk angka. Jenis penelitian yang digunakan bersifat penelitian analitik korelatif, metode analitik korelatif adalah suatu metode 
dengan tujuan untuk mengetahui ada atau tidaknya hubungan suatu data, dan apabila ada, seberapa erat hubungan serta berarti atau tidaknya hubungan itu.

\subsection{Subjek penelitian}

Populasi penelitian ini adalah mahasiswa program studi Teknik Sipil Fakultas Teknik Universitas Sulawesi Barat. Sampel yang diambil kurang lebih $10 \%$ dari jumlah populasi, sehingga sampel dalam penelitian ini berjumlah 30 Mahasiswa.

\subsection{Alur penelitian}

Alur penelitian dalam skripsi ini menjelaskan mengenai tahapan atau prosedur penelitian untuk mengetahui ada atau tidaknya hubungan nilai mata kuliah matematika rekayasa terhadap nilai analisa struktur. Berikut merupakan diagram alur penelitian yang dimulai dari persiapan dalam menentukan tujuan penelitian, tahapan-tahapan penelitian hingga hasil akhir penelitian.

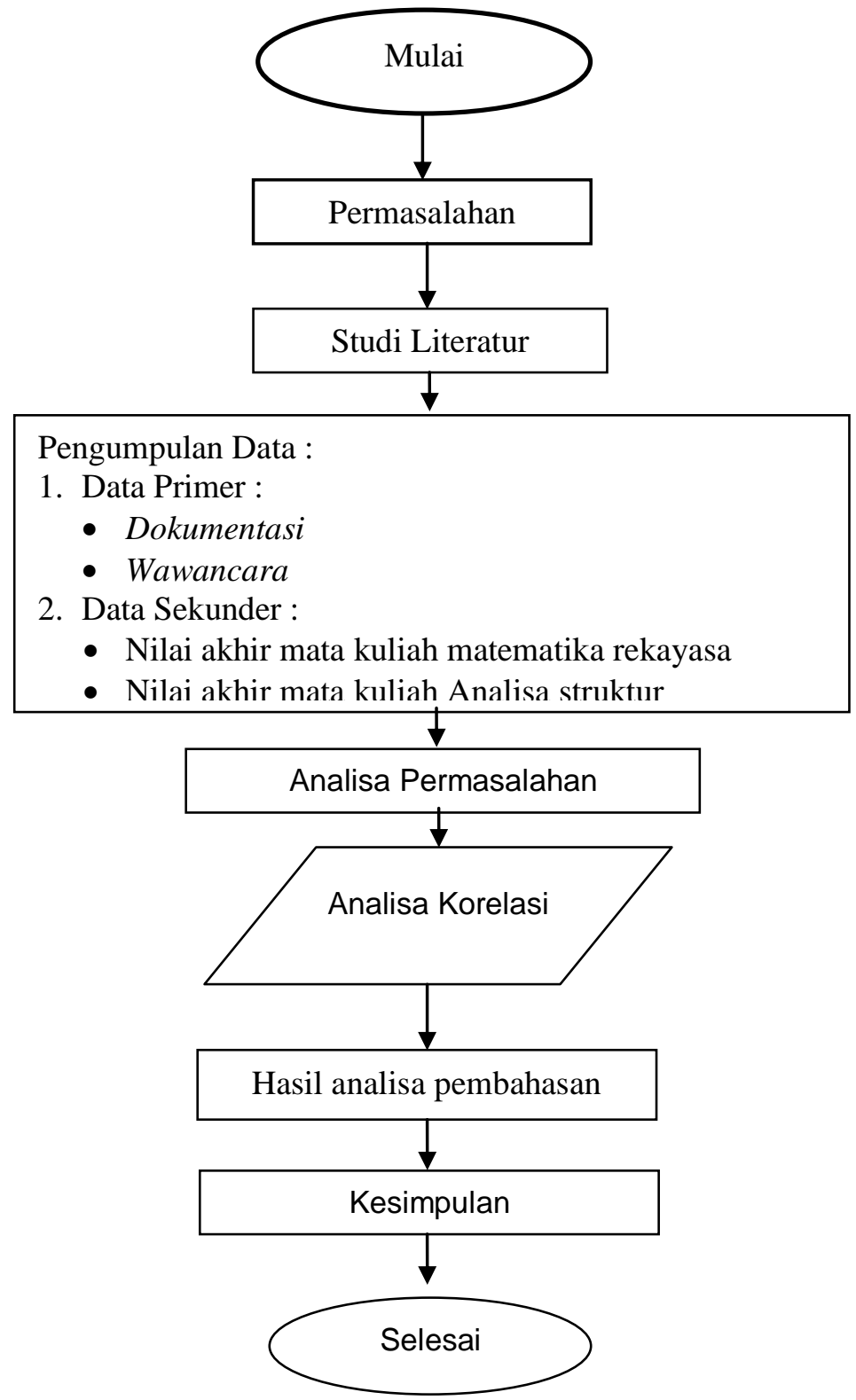

Gambar 1. Diagram alur penelitian 


\subsection{Teknik Pengumpulan Data}

Pengumpulan data dalam penelitian ini menggunakan metode dokumentasi. Data yang dikumpulkan adalah nilai mata kuliah Matematika rekayasa dan nilai mata kuliah Analisa struktur pada program studi Teknik Sipil Universitas Sulawesi barat pada nilai satu semester. Menurut murfi (2016), metode dokumentasi adalah metode yang digunakan untuk mencari data mengenai hal-hal atau variabel yang berupa catatan, transkrip, buku, dan sebagainya.

\subsection{Teknik Analisis Data}

Penelitian ini menggunakan Random Sampling yaitu pengambilan sampel yang dilakukan dengan cara "acak". Teknik ini dimaksudkan untuk memperoleh sampel yang representatif yaitu tiap-tiap individu dalam populasi diberi kesempatan yang sama untuk ditugaskan menjadi anggota sampel.Variabel dalam penelitian ini ada dua yaitu variabel bebas dan variabel terikat. Variabel bebas merupakan variabel yang mempengaruhi atau yang menjadi sebab perubahannya atau timbulnya variabel terikat.

Variabel bebas dalam penelitian ini adalah nilai mata kuliah Matematika rekayasa. Menurut Sugiyono (2013), Variabel terikat adalah variabel yang dipengaruhi atau yang menjadi akibat, karena adanya variabel bebas. Variabel terikat dalam penelitian ini adalah nilai mata kuliah Analisa struktur. Nilai yang diteliti adalah nilai akhir satu semester.

Analisa data yang digunakan dalam penelitian ini adalah analisis korelasi pearson atau biasa disebut dengan analisis product moment yang digunakan untuk mengukur hubungan antara dua variabel secara linier dan untuk mengetahui arah hubungan yang terjadi antara variabel $\mathrm{x}$ dan $\mathrm{y}$. maka digunakan rumus korelasi Pearson (Product Moment) sebagai berikut:

$\mathrm{f}-$ hitung $=\frac{n(\Sigma x y)-(\Sigma x) \cdot(\Sigma y)}{\sqrt{\left.\left.\{n \cdot \Sigma y)^{2}\right\} \cdot\left\{n \cdot \Sigma y^{2}-(\Sigma y)^{2}\right\}\right\}}}$

$$
\begin{array}{ll}
\text { Keterangan : } \\
\text { f-hitung } & =\text { Koefisien Korelasi } \\
\mathrm{X} & =\text { Variabel Bebas } \\
\mathrm{Y} & =\text { Variabel Terikat } \\
\mathrm{n} & =\text { Jumlah Responden }
\end{array}
$$

Penelitian ini menggunakan taraf signifikansi 5\% sehingga dalam menarik kesimpulan hasil pengolahan data adalah sebagai berikut:

1) Apabila nilai koefisien hubungan (r) yang diperoleh dari hubungan perhitungan lebih besar (>) dari nilai $\mathrm{r}$ yang ada pada tabel, makaitu berarti hipotesis yang diajukan terbukti kebenarannya $\left(r_{0}>r_{t} \ldots H 0\right.$ diterima $)$.

2) Apabila nilai $r$ yang diperoleh dari hubungan perhitungan kurang dari $(<)$ dari nilai $r$ yang ada pada tabel, maka itu berarti hipotesa yang diajukan tidak terbukti kebenarannya $\left(\mathrm{r}_{0}<\right.$ $\mathrm{r}_{\mathrm{t}} \ldots \mathrm{H} 0$ ditolak).

Dimana:

$\mathrm{r}_{0} \quad=$ Koefisien hubungan dari perhitungan yang diperoleh

$\mathrm{r}_{\mathrm{t}} \quad=$ Koefisien pada tabel dengan interprestasi nilai $\mathrm{r}$ seperti pada tabel berikut:

Nilai korelasi pearson dilambangkan (r) dengan ketentuan nilai $\mathrm{r}$ tidak lebih dari harga $(-1 \leq \mathrm{r}$ $\geq+1$ ). Apabila nilai $r=-1$ artinya korelasinya negatif sempurna, bila $r=0$ artinya tidak ada korelasi dan $r=1$ berarti korelasinya sangat kuat. Sedangkan arti harga $r$ dikonsultasikan dengan tabel interprestasi nilai $r$ sebagai berikut : 
Tabel 1 Pedoman Interprestasi terhadap koefisien korelasi

\begin{tabular}{|l|l|}
\hline \multicolumn{2}{|c|}{ Interval Koefisien Tingkat Hubungan } \\
\hline $0,00-0,199$ & Sangat rendah \\
$0,20-0,399$ & Rendah \\
$0,40-0,599$ & Sedang \\
$0,60-0,799$ & Kuat \\
$0,80-1,000$ & Sangat kuat \\
\hline
\end{tabular}

\section{HASIL DAN PEMBAHASAN}

\subsection{Penyajian Data}

Penyajian data dalam penelitian ini menggunakan 30 sampel dalam hal ini nilai mahasiswa diambil secara acak dari data nilai akhir yang diperoleh pada ujian akhir semester mahasiswa program studi teknik sipil angkatan 2015/2016 pada mata kuliah Matematika rekayasa dan mata kuliah Analisa struktur yang dapat dilihat pada tabel berikut:

Tabel 2. Data Nilai dari anggota sampel

\begin{tabular}{|c|c|c|}
\hline No & $\begin{array}{c}\text { Matematika } \\
\text { Rekayasa }\end{array}$ & $\begin{array}{c}\text { Analisa } \\
\text { Struktur }\end{array}$ \\
\hline 1 & 60,00 & 75,00 \\
\hline 2 & 70,00 & 45,50 \\
\hline 3 & 60,00 & 40,00 \\
\hline 4 & 85,00 & 70,00 \\
\hline 5 & 67,50 & 65,00 \\
\hline 6 & 83,25 & 61,25 \\
\hline 7 & 70,00 & 80,00 \\
\hline 8 & 60,00 & 50,00 \\
\hline 9 & 70,00 & 75,00 \\
\hline 10 & 85,00 & 60,00 \\
\hline 11 & 60,00 & 35,00 \\
\hline 12 & 78,50 & 60,58 \\
\hline 13 & 83,00 & 65,15 \\
\hline 14 & 67,05 & 55,00 \\
\hline 15 & 73,15 & 50,00 \\
\hline 16 & 68,75 & 62,15 \\
\hline 17 & 85,50 & 67,35 \\
\hline 18 & 70,00 & 81,25 \\
\hline 19 & 50,00 & 35,50 \\
\hline 20 & 65,00 & 71,25 \\
\hline 21 & 80,00 & 75,00 \\
\hline 22 & 85,00 & 70,00 \\
\hline 23 & 70,00 & 66,76 \\
\hline 24 & 50,00 & 60,00 \\
\hline 25 & 74,20 & 69,00 \\
\hline 26 & 60,00 & 20,00 \\
\hline 27 & 60,00 & 35,00 \\
\hline 28 & 72,00 & 40,00 \\
\hline 29 & 71,50 & 56,20 \\
\hline 30 & 68,60 & 90,00 \\
\hline
\end{tabular}




\subsection{Analisis Data}

Dari perolehan nilai mata kuliah matematika rekayasa dan mata kuliah analisa struktur mahasiswa teknik sipil universitas sulawesi barat yang ada pada tabel 2. Maka dapat digambarkan proyeksi grafik dari masing-masing variabel yang diuji. Dari data yang diperoleh nilai terendah untuk mata kuliah matematika rekayasa adalah nilai 50 sedangkan yang tertinggi adalah nilai 85. Untuk mata kuliah analisa struktur, perolehan nilai terendah adalah nilai 20 dan yang tertinggi nilai 90 .

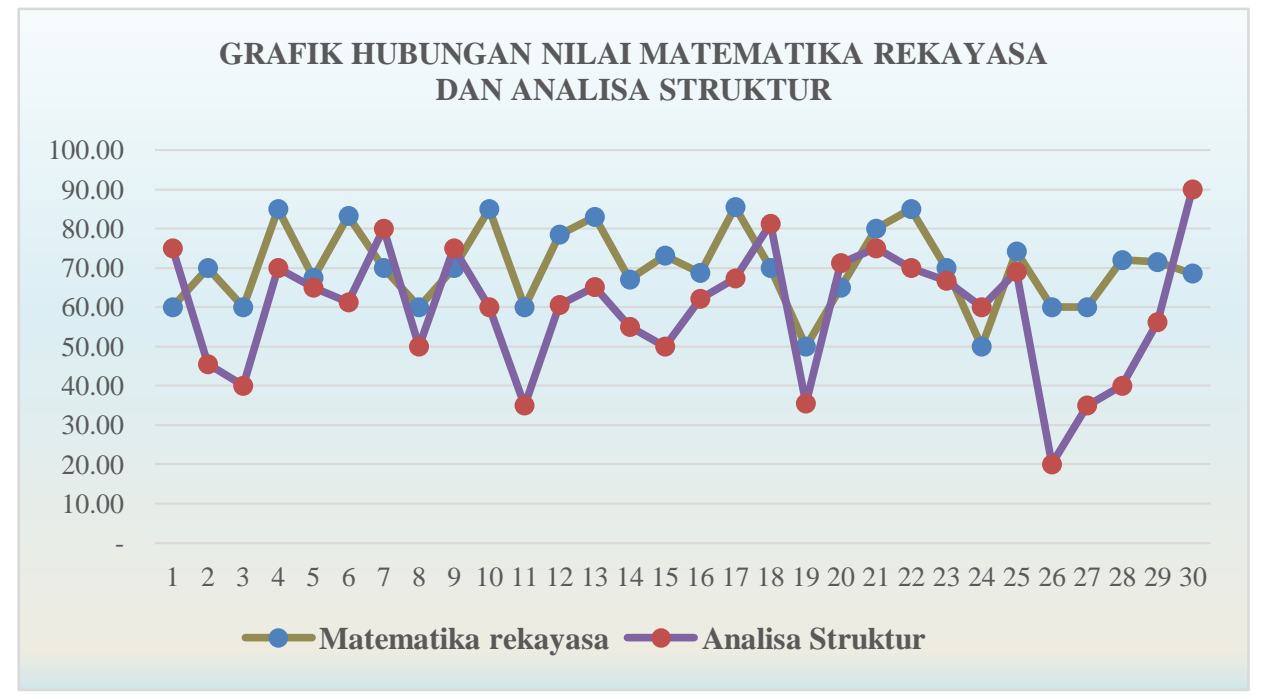

Gambar 1 Grafik Hubungan Nilai Matematika rekayasa terhadap Analisa Struktur

Berdasarkan gambar 1 menunjukkan bahwa dari 30 sampel nilai mahasiswa yang diambil secara acak, menunjukkan hubungan perbedaan yang sedang antara nilai mata kuliah matematika rekayasa dengan nilai mata kuliah analisa struktur. Dari gambar tersebut dapat disimpulkan bahwa antara mata kuliah matematika rekayasa dengan nilai mata kuliah analisa struktur memiliki hubungan yang sedang. Selanjutnya dari data perolehan nilai, di analisis dengan menggunakan bantuan program software SPSS ver. 21 untuk uji korelasi pearson dan uji signifikansi nilai mata kuliah matematika rekayasa terhadap mata kuliah analisa struktur agar pernyataan tersebut terbukti kebenarannya.

Tabel 3 Hasil Korelasi nilai Matematika rekayasa terhadap Analisa Struktur

\begin{tabular}{|c|c|c|c|}
\hline \multicolumn{4}{|c|}{ Correlations } \\
\hline & & $\begin{array}{c}\text { Matematika } \\
\text { Rekayasa }\end{array}$ & $\begin{array}{l}\text { Analisa } \\
\text { Struktur }\end{array}$ \\
\hline \multirow[t]{3}{*}{ Matematika_Rekayasa } & Pearson Correlation & 1 & $435^{*}$ \\
\hline & \begin{tabular}{|l|} 
Sig. (2-tailed) \\
\end{tabular} & & ,016 \\
\hline & $\mathrm{N}$ & 30 & 30 \\
\hline \multirow[t]{3}{*}{ Analisa_Struktur } & Pearson Correlation &, $435^{*}$ & 1 \\
\hline & Sig. (2-tailed) & 016 & \\
\hline & $\mathrm{N}$ & 30 & 30 \\
\hline
\end{tabular}

Berdasarkan analisis pada tabel 3 dengan menggunakan bantuan program software SPSS ver. 21 untuk uji korelasi pearson maka diperoleh nilai Signifikansi dengan tingkat kesalahan 5\% $(0,016<0,05)$ maka Ho ditolak, artinya bahwa ada hubungan secara signifikan 
antara nilai mata kuliah matematika rekayasa dengan nilai mata kuliah analisa struktur. Nilai koefisien korelasi diperoleh nilainya positif artinya terjadi hubungan positif antara perolehan nilai mata kuliah matematika rekayasa dan mata kuliah analisa struktur, namun keeratan hubungannya dikategorikan sedang karena nilai interpretasi terhadap koefisien korelasi berada pada interval nilai $0,40-0,599$ yaitu sebesar 0435 .

Dari tabel diperoleh nilai $\mathrm{r}_{\text {tabel }}$ sebesar 0,361 untuk sampel sebanyak 30 mahasiswa, maka dapat disimpulkan bahwa ( $\mathrm{r}_{\text {-hitung }}=0,435>\mathrm{r}_{\text {-tabel }}=0,361$ ) berarti Ho diterima, namun hubungan antara nilai Matematika rekayasa terhadap nilai mata kuliah analisa struktur tidak ada hubungannya karena meskipun nilai mata kuliah Matematika rekayasa tinggi belum tentu nilai mata kuliah analisa struktur juga tinggi.

\section{KESIMPULAN}

1. Berdasarkan hasil penelitian mengenai Hubungan antara nilai Matematika rekayasa dan Analisa struktur maka dapat dikategorikan sedang karena karena nilai interpretasi terhadap koefisien korelasi berada pada interval nilai $0,40-0,599$ yaitu sebesar 0435. Artinya memiliki hubungan yang sedang atau dapat dikatakan sedikit pengaruhnya meskipun berkorelasi positif, namun hasilnya tidak signifikan atau tidak bisa digeneralisasikan ke dalam populasi. Hal ini menunjukkan bahwa nilai mata kuliah matematika rekayasa yang diperoleh tidak memiliki hubungan yang signifikan terhadap nilai mata kuliah analisa struktur yang diperoleh.

2. Nilai korelasi antara nilai Matematika rekayasa terhadap nilai analisa struktur adalah sebesar 0.435 dengan signifikansi pada taraf kesalahan 5\% dan didapat $\mathrm{r}_{-}$tabel 0,361 maka ( $\left.\mathrm{r}_{- \text {hitung }}=0,435>\mathrm{r}_{\text {tabel }}=0,361\right)$ berarti Ho diterima, namun hubungan antara nilai Matematika rekayasa terhadap nilai mata kuliah analisa struktur tidak ada hubungannya karena meskipun nilai mata kuliah Matematika rekayasa tinggi belum tentu nilai mata kuliah analisa struktur juga tinggi.

\section{DAFTAR PUSTAKA}

Iswadi, Hazrul. dkk. 2006. Kalkulus. Malang: Bayumedia Publishing

Murfi,henni, Weni. 2014. Mekanika Teknik Semester 1 kelas X. Kemendikbud

M. Iqbal Alfiddin Malik, 2016 Jurnal Kajian Pendidikan Teknik Bangunan Vol 3 Nomor 3/JKPTB/16(2016), 207 - 212

Sazhin, S.S. 1998. Teaching Mathematics to Engineering Students. Int. J. Eng Ed. Vol. 14, No. 2, P. $145 \pm 152,1998,14(2), 8$.

Siswanto. 2005. Matematika Inovatif 1 Konsep dan Aplikasinya. Solo : PT Tiga Serangkai Pusaka Mandiri.

Sugiyono, 2014. Metode Penelitian Pendidikan (Pendekatan Kuantitatif, Kualitatif dan R\&D). Bandung: Alfabeta.

Sukardi.2012. Metodologi Penelitian Pendidikan Kompetensi dan Praktiknya.Jakarta : Bumi Aksara

Sundayana, Rostina. 2013. Media PendidikanMatematika (untuk guru, calon guru, orang tua, dan para pecinta matematika). Bandung : Alfabeta.

Sutriningsi, Naning. 2015. Model Pembelajaran Assisted Individualization Berbasis Assessment For Learning pada Persamaan Garis Lurus ditinjau dari Karakteristik Cara Berpikir. Jurnal, tersediadi :http/e-DuMath//jurnal vol-1-no-1/43/51.pdf (2 Agustus 2015).

Usniati, Mia. 2011. Meningkatkan kemampuan Penalaran Matematika melalui Pendekatan Pemecahan Masalah. Jurnal, tersedia di: http://respository.uinjkt.ac.id/dspace/bits.pdf (20 Februari 2015).

Wahid murni. 2010. Evaluasi Pembelajaran Kompetensi dan Praktik. Yogyakarta: Nuha Litera.

Hubungan Nilai Matematika Rekayasa Terhadap Nilai Analisa Struktur Mahasiswa Teknik Sipil Universitas Sulawesi Barat (Milawaty Waris) 